\title{
Development of a sensitive long path absorption photometer to quantify peroxides in aerosol particles (Peroxide-LOPAP)
}

\author{
P. Mertes ${ }^{1}$, L. Pfaffenberger ${ }^{1}$, J. Dommen ${ }^{1}$, M. Kalberer ${ }^{2}$, and U. Baltensperger ${ }^{1}$ \\ ${ }^{1}$ Paul Scherrer Institute, Laboratory of Atmospheric Chemistry, Villigen, Switzerland \\ ${ }^{2}$ Centre for Atmospheric Science, Department of Chemistry, University of Cambridge, UK \\ Correspondence to: J. Dommen (josef.dommen@psi.ch)
}

Received: 16 January 2012 - Published in Atmos. Meas. Tech. Discuss.: 13 February 2012

Revised: 25 July 2012 - Accepted: 31 July 2012 - Published: 2 October 2012

\begin{abstract}
A new off-line instrument to quantify peroxides in aerosol particles using iodometry in long path absorption spectroscopy has been developed and is called peroxide long path absorption photometer (Peroxide-LOPAP). The new analytical setup features important technical innovations compared to hitherto published iodometric peroxide measurements. Firstly, the extraction, chemical conversion and measurement of the aerosol samples are performed in a closed oxygen-free ( $\sim 1 \mathrm{ppb})$ environment. Secondly, a 50 -cm optical detection cell is used for an increased photometric sensitivity. The limit of detection was $0.1 \mu \mathrm{M}$ peroxide in solution or $0.25 \mathrm{nmol} \mathrm{m}^{-3}$ with respect to an aerosol sample volume of $1 \mathrm{~m}^{3}$. The test reaction was done at a constant elevated temperature of $40^{\circ} \mathrm{C}$ and the reaction time was $60 \mathrm{~min}$.

Calibration experiments showed that the test reaction with all reactive peroxides, i.e. hydrogen peroxide $\left(\mathrm{H}_{2} \mathrm{O}_{2}\right)$, peracids and peroxides with vicinal carbonyl groups (e.g. lauroyl peroxide) goes to completion and their sensitivity (slope of calibration curve) varies by only $\pm 5 \%$. However, very inert peroxides have a lower sensitivity. For example, tert-butyl hydroperoxide shows only $37 \%$ sensitivity compared to $\mathrm{H}_{2} \mathrm{O}_{2}$ after $1 \mathrm{~h}$. A kinetic study revealed that even after $5 \mathrm{~h}$ only $85 \%$ of this inert compound had reacted.

The time trends of the peroxide content in secondary organic aerosol (SOA) from the ozonolysis and photooxidation of $\alpha$-pinene in smog chamber experiments were measured. The highest mass fraction of peroxides with $34 \%$ (assuming a molecular weight of $300 \mathrm{~g} \mathrm{~mol}^{-1}$ ) was found in freshly generated SOA from $\alpha$-pinene ozonolysis. Mass fractions decreased with increasing NO levels in the photooxidation experiments. A decrease of the peroxide content was also observed with aging of the aerosol, indicating a decomposition of peroxides in the particles.
\end{abstract}

\section{Introduction}

Beside their decisive role in atmospheric processes ambient fine and ultrafine particles have also an important impact on human health, predominantly on respiratory and cardiovascular systems (Pope and Dockery, 2006; Pope et al., 2009). Up to about $70 \%$ of these ambient particles are composed of organic material (Jimenez et al., 2009). However, the highly complex organic mixture is chemically still poorly characterized (Hallquist et al., 2009). The reaction of volatile organic compounds with ozone and $\mathrm{OH}$ radicals in the polluted troposphere generates a variety of oxygenated organic compounds like aldehydes, ketones, carboxylic acids, nitrates and organic hydroperoxides of low volatility, which can partition into aerosols (Atkinson, 2000; Atkinson and Arey, 2003; Kroll and Seinfeld, 2008). Organic hydroperoxides are generated in the atmosphere in three different ways: (1) by gas phase reactions of $\mathrm{HO}_{2}$ radicals with organic peroxy radicals $\mathrm{RO}_{2}$ (e.g. Atkinson, 2000), (2) via the reaction of water with "Criegee intermediates" from alkene ozonolysis (e.g. Hasson et al., 2001) and (3) by aqueous-phase photochemical reactions in atmospheric water (e.g. Faust et al., 1993). Depending on the volatility and solubility of these peroxides they partition more or less into the particle phase. Model simulations predict organic hydroperoxides to be major contributors of secondary organic aerosol mass (Bonn et al., 2004; Johnson et al., 2004). The contribution of peroxides to health risk is assumed to be important because of their high reactivity and oxidation potential (Morio et al., 2001). Besides the interest in the formation and chemical composition of aerosols this is another important motivation to analyse the content of hydrogen peroxide and organic peroxides in secondary organic aerosol (SOA). 
Along with several methods to analyse peroxides, the most widely used techniques are based on electrochemical reduction (e.g. Qi and Baldwin, 1993) and fluorometric detection of a fluorescing dimer, which is produced from the derivatization of a peroxide catalysed by the enzyme horseradish peroxidase (e.g. Lazrus et al., 1985; Kok et al., 1986; Wang and Glaze, 1998). However, the relevant drawbacks of these detection methods are different sensitivities for different peroxide species as well as the missing accessibility for dialkyl peroxides, which need to be hydrolysed first. Moreover, an aqueous solvent is required to sustain the catalytic activity of the enzyme. This hinders the quantitative extraction of less water soluble peroxides from the particles.

We used iodometry for quantification of the total peroxide content (Banerjee and Budke, 1964). This method was already applied in other studies to measure the peroxide content of aerosols (Docherty et al., 2005; Ziemann, 2005; Surratt et al., 2006; Nguyen et al., 2010). Herein peroxy-groups oxidize iodide ions $\left(\mathrm{I}^{-}\right)$to molecular iodine $\left(\mathrm{I}_{2}\right)$ in solution which subsequently forms yellow coloured triiodide ions $\left(\mathrm{I}_{3}^{-}\right)$. However, molecular oxygen reacts in the same way with iodide ions, which is a major drawback of this method. We minimised the influence of oxygen by constructing a closed oxygen-free instrument.

Furthermore, due to insensitive spectrophotometry with $1-\mathrm{cm}$ cuvettes, the experiments in former studies had to be performed at very high aerosol concentrations and the time resolution was rather low (2-4h) (e.g. Surratt et al., 2006). Peroxide mass fractions from $20 \%$ to over $100 \%$ were reported in SOA from various precursors assuming a molecular weight of $300 \mathrm{~g} \mathrm{~mol}^{-1}$ for peroxides (Docherty et al., 2005; Ziemann, 2005; Surratt et al., 2006; Nguyen et al., 2010). To enhance the sensitivity we developed a long path absorption spectroscopy system. According to Lambert-Beer's law, the sensitivity of spectrophotometry can be enhanced by increasing the optical path length. However, this requires that the background from the reagents can be kept at a low level. This sensitive analytical method has already been successfully applied in different colorimetric detection studies (e.g. Yao et al., 1998; Heland et al., 2001; Callahan et al., 2002). In analogy to the original long path absorption photometer (LOPAP) which was developed for HONO measurements (Kleffmann et al., 2002), we call the instrument Peroxide-LOPAP.

\section{Experimental}

To measure peroxides in aerosol particles with our new Peroxide-LOPAP, samples are collected either via impaction on steel plates or behind a charcoal denuder on Teflon filters. These samples are then extracted under anaerobic conditions in an aqueous solution of hydrochloric acid $(\mathrm{pH} 1)$ and ethanol ( $1: 1$ by volume) at $40^{\circ} \mathrm{C}$. Extraction and the iodometric test reaction of peroxides with iodide ions take place at the same time since the solvent mixture initially contains potassium iodide (KI) as well. Anaerobic conditions are essential because molecular oxygen reacts competitive to peroxides. Triiodide ions are formed in situ from generated iodine and excess KI. After $60 \mathrm{~min}$ their absorbance is measured using a long path detection cell (liquid core waveguide, $\mathrm{LCW}$ ) and a photometer.

\subsection{Analyser setup}

Figure 1 presents a schematic of the new instrumental setup. The reaction vessel, the solvents, the liquid pump as well as the liquid core waveguide (LCW) are situated in an air tight PVC housing. This is permanently flushed with nitrogen (99.999\%, "5.0"). Liquids have to pass a PTFE (polytetrafluoroethylene) in-line filter (Omnifit 003305 , porosity $25 \mu \mathrm{m}$ ) before entering the LCW. Ultrapure nitrogen (UPN) is produced from nitrogen (Carbagas, Alphagaz $2 \mathrm{~N}_{2}, 99.9999 \%$, $<0.1 \mathrm{ppm} \mathrm{O}_{2}$ ) with a gas purifier (Entegris, GateKeeper). This setup reduces the oxygen content to about $1 \mathrm{ppb}$, according to the manufacturer. Each solvent is purged for oxygen by bubbling with UPN before use in the test reaction. We exclusively use chemically resistant PTFE or PEEK (polyetheretherketone) tubings and fittings in the instrument. PTFE is known to be permeable to oxygen (Dobson and Taylor, 1986; Giacobbe, 1990) which requires that the entire extraction and measurement set up is placed in an oxygenfree atmosphere housing. Stainless steel tubings are used for nitrogen outside the housing. The piston cylinder and piston are made from ceramic and the cylinder case from Tefzel (Ismatec, REGLO-CPF RH00.CTC-LF). As detection cell we use a Teflon AF $2400 \mathrm{LCW}$ tube (DuPont, $0.6 \mathrm{~mm}$ I.D.). This special type of Teflon differs from commonly used polyfluorocarbons by its very low index of refraction of 1.29 only (Resnick and Buck, 1999). Filled with water or ethanol the light is totally reflected inside the capillary. The optical path length was measured to be $0.46 \mathrm{~m}$. The absorbance is measured by a spectrophotometer (Ocean Optics, SD 2000). White light is supplied via a 200- $\mu \mathrm{m}$ glass fiber (Fiber Optic, Switzerland, "Lichtleiter mit Quarzfaser" SFS200/220T UVVIS) from a deuterium lamp (Avantes, AvaLight-DH-S). The glass fiber, the solvent tubing and the LCW are connected inside the housing via Tee fittings (VICI AG International, high pressure PEEK, 1/32" fingertight nuts, bore $0.5 \mathrm{~mm}$ ). The glass fibers are connected to these Tees via Nanovolume column replacement liners (VICI AG International, high pressure PEEK, $27 \mathrm{~mm}, 1 / 32^{\prime \prime}$ O.D., bore 225-250 $\mu \mathrm{m}$ ). This system is easy to install, allows to change the LCW as well as the glass fibers easily and is air tight.

The test reaction takes place in a FIOLAX test tube (approx. $5 \mathrm{ml}, 10 \times 75 \mathrm{~mm}$, Duran group) as reaction vessel. It is tightly closed with a rubber plug containing the PTFE tubings for liquids and UPN. This reaction solution is mixed by bubbling UPN via a glass capillary. The reaction vessel is placed in an aluminium block, which can be heated by two heating elements delivering an output power of $10 \mathrm{~W}$. 


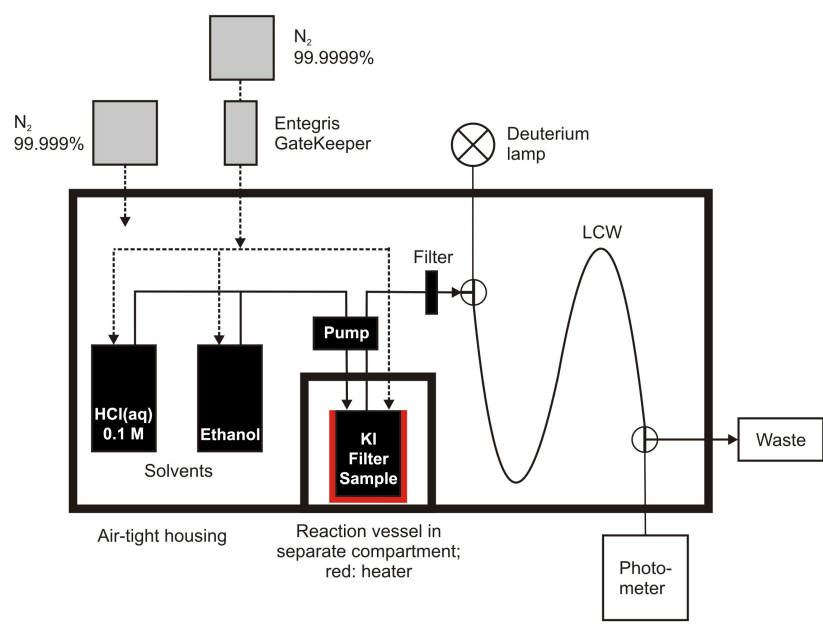

Fig. 1. Setup of the Peroxide-LOPAP. All tubings, fittings, vessels and the pump are positioned in an air-tight PVC housing under a nitrogen atmosphere $(99.999 \%)$. To position the reaction vessel into the analyser only that compartment has to be opened. Adding solvents into the reaction vessel as well as the triiodide solution into the $\mathrm{LCW}$, the analyser has not to be opened. Before use, each solvent is purged of oxygen by bubbling with nitrogen $(99.9999 \%)$ cleaned with a gas purifier (Entegris, GateKeeper).

With this heater the temperature of the reaction solution in the reaction vessel can be elevated from $22^{\circ} \mathrm{C}$ to about $39^{\circ} \mathrm{C}$ within $2.5 \mathrm{~min}$. This is very quick compared to the reaction time of $60 \mathrm{~min}$. For each analysis, the test tube as well as the glass capillary was replaced by new ones.

\subsection{Analysis protocol}

Samples were extracted and reacted in $2.5 \mathrm{ml}$ of $0.1 \mathrm{M}$ $\mathrm{HCl}_{(\mathrm{aq})} /$ ethanol (1:1 by volume) containing $26 \pm 0.3 \mathrm{mg}$ of potassium iodide $(\mathrm{KI}, 63 \pm 0.7 \mathrm{mM})(18 \mathrm{M} \Omega \mathrm{cm}$ water; ethanol: Merck, EMSURE ${ }^{\circledR}$, absolute for analysis; KI: Fisher Scientific). First, the reaction vessel containing the KI and the filter sample is placed in the heater within the reaction vessel compartment. This is then closed and the KI and the filter sample are flushed with ultrapure nitrogen (UPN) for $10 \mathrm{~min}$. Then deoxygenated solvents are filled into the tube without opening the analyser housing. The heater is switched on during the filling time $(\sim 4 \mathrm{~min})$ and reaches $40^{\circ} \mathrm{C}$ by the end of the filling.

To avoid semi-volatile compounds to evaporate from the aerosol samples while flushing with UPN, the aluminium heating block is cooled down from $40^{\circ} \mathrm{C}$ to room temperature (RT) after each analysis with cooling spray. Homogeneous mixing of the sample is achieved by bubbling UPN at the beginning of the extraction/reaction as well as after $60 \mathrm{~min}$ right before the photometric detection. A positive nitrogen pressure within all vessels is sustained during the analysis. At the end of the reaction, the mixture is pumped into the LCW to record the absorption spectrum.

\subsection{Aerosol sampling and extraction}

We used two different methods to sample aerosol particles: impaction and filter sampling. The aerosol mass collected was quantified gravimetrically (METTLER MT5, Max $5.1 \mathrm{~g}$, $\pm 1 \mu \mathrm{g})$.

For impaction we used an impactor described by Williams et al. (2006) with a particle size cut point $D_{50}=85 \mathrm{~nm}$. Particles impact on A4-steel plates (1 mm thickness) to ensure a flat surface. These steel plates are easier to handle compared to thin Teflon or aluminum foils and guarantee a constant distance between critical orifice and sampling surface. Due to a high chromium content of A4-steel (16-18.5\%, X5CrNiMo 17-12-2, DIN EN 10088-3), these plates are inert and do not influence the test reaction as could be shown by blank (i.e. pure potassium iodide) experiments. The use of an impactor does not need a charcoal denuder to remove organic gases. However, the collection efficiency was just only $43 \%$ as measured by gravimetry. The flow rate of the impactor was $7.21 \mathrm{~min}^{-1}$.

For filter sampling we used $17 \mathrm{~mm}$ PTFE membranes (Fluoropore Membrane, $3.0 \mu \mathrm{m}$, Millipore FSLW04700 or Fluoropore Membrane, $1.0 \mu \mathrm{m}$, Millipore FALP04700) behind a charcoal denuder to remove organic gas phase components. Flow rates were $14-151 \mathrm{~min}^{-1}$ for $3.0 \mu \mathrm{m}$ pore size and 8 $91 \mathrm{~min}^{-1}$ for $1.0 \mu \mathrm{m}$ pore size. This type of sampling may suffer from positive artifacts from adsorbing gaseous species (if the denuder is not $100 \%$ efficient) or negative artifacts by evaporation of semi-volatile species from the filter. The sampling times varied between 30 and 120 min depending on the aerosol mass concentration and sampling flow rate. During an experiment up to 5 samples were taken and analysed.

The aerosol sample on the filter or impactor steel plate stays in the reaction test tube during the entire reaction time. Hence, even peroxide species with a very low solubility in water or ethanol (e.g. benzoyl peroxide, lauroyl peroxide) are extracted and converted in the test reaction. Some extracted aerosol components may absorb visible or UV-light as well, as shown by Hecobian et al. (2010). To account for this interference of absorbing aerosol components on the photometric peroxide measurements, the Teflon filters were cut in two halves and one half was analysed without potassium iodide. In this way the background absorbance of the aerosol was subtracted from the triiodide signal.

\subsection{Data acquisition}

The absorbance was recorded using the software OOIBase 32 (Ocean Optics). A reference spectrum was taken from the solvent mixture of $0.1 \mathrm{M} \mathrm{HCl}_{(\mathrm{aq})} /$ ethanol (1:1 by volume). To account for intensity fluctuations (e.g. caused by bubbles of nitrogen entering the detection cell) the recorded absorbance from triiodide was corrected with the absorbance at $542 \mathrm{~nm}$ where triiodide does not absorb and the intensity of the deuterium lamp is still high. 
Table 1. Organic peroxides used in this study. benzoyl peroxide

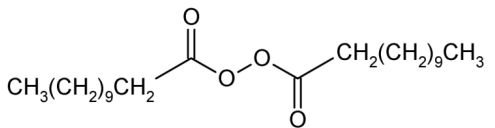

lauroyl peroxide<smiles>O=C(OOC(=O)c1ccccc1)c1ccccc1</smiles>

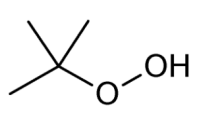

tert-butyl hydroperoxide<smiles>CC(=O)OO</smiles>

peracetic acid

\section{Results and discussion}

\subsection{Calibration}

Several peroxide species were used to calibrate the PeroxideLOPAP. Standards were prepared from solutions of hydrogen peroxide $\left(\mathrm{H}_{2} \mathrm{O}_{2}\right.$; Sigma-Aldrich, solution, $3 \mathrm{wt}$.\% in water $)$, peracetic acid (PAA; Sigma-Aldrich, $\sim 39 \%$ in acetic acid, $\left.\leq 6 \% \mathrm{H}_{2} \mathrm{O}_{2}\right)$, tert-butyl hydroperoxide (tBuOOH; Aldrich, Luperox ${ }^{\circledR}$ TBH70X, $70 \mathrm{wt}$ \% in water), benzoyl peroxide (BenP; Aldrich, Luperox ${ }^{\circledR}$ A75, $75 \%$, remainder water) and lauroyl peroxide (LP; Aldrich, Luperox ${ }^{\circledR}$ LP, $97 \%$ ). Table 1 gives an overview of the chemical structures. Water soluble peroxides, i.e. $\mathrm{H}_{2} \mathrm{O}_{2}$, PAA and $\mathrm{tBuOOH}$, were added in different amounts to the reaction vessel as aqueous solution $(40 \mu \mathrm{M})$. Solutions were positioned separately within the airtight housing and purged for molecular oxygen with ultrapure nitrogen (UPN, see Sect. 2.1) before use. Blank values were measured from the solvent plus potassium iodide (KI). BenP and LP are soluble neither in water nor in ethanol. Therefore, standard solutions were prepared in ethyl acetate (Fluka, purum) and $2.5 \mu$ thereof were pipetted on a Teflon filter and the filter was analysed analogously to an aerosol filter sample (see Sect. 2.3). The blank values were obtained using a clean Teflon filter.

All samples were allowed to react for $60 \mathrm{~min}$ at $40^{\circ} \mathrm{C}$. In Fig. 2 the resulting absorbance spectra for $\mathrm{H}_{2} \mathrm{O}_{2}$ are shown. The absorbance at $420 \mathrm{~nm}$ is used for calibration and sample measurement. The presence of triiodide ions in the blank measurement may result from iodine traces in KI or remaining impurities of molecular oxygen. The level of background absorbance was already reached after $15 \mathrm{~min}$ of reaction.

Figure 3 presents the calibration curves of different peroxide standards. In Fig. 3a the absorbance data at $420 \mathrm{~nm}$ for all measured peroxides in the concentration range 0 to $6 \mu \mathrm{M}$ and the resulting linear least squares regression fits are shown. All these calibration curves are similar except that of $\mathrm{tBuOOH}$. At this wavelength, absorbance values up to 1 correlate linearly to the peroxide concentration. The slopes of the reactive peroxides vary between 0.163 and 0.181 giving

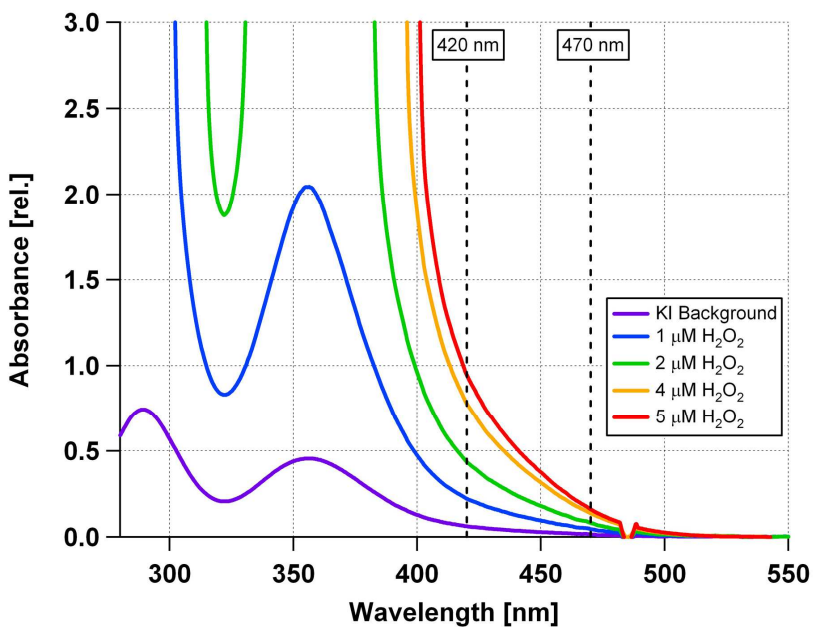

Fig. 2. Absorption spectra of triiodide in $0.1 \mathrm{M}$ aqueous $\mathrm{HCl} /$ ethanol (1:1 by volume). Triiodide ions were produced from the reaction of hydrogen peroxide $\left(\mathrm{H}_{2} \mathrm{O}_{2}\right)$ at different concentrations with iodide ions. The concentration of potassium iodide (KI) was $63 \mathrm{mM}$. The background spectrum was recorded from the pure $\mathrm{KI}$ solution. Absorbance values at $420 \mathrm{~nm}$ and $470 \mathrm{~nm}$ were taken for calibration.

an average slope of $0.172 \pm 0.009(= \pm 5.2 \%)$. Other studies used BenP (Docherty et al., 2005; Surratt et al., 2006) or $\mathrm{H}_{2} \mathrm{O}_{2}$ (Nguyen et al., 2010) to calibrate their measurements. According to Fig. 3a, these calibration curves can be used equally.

In contrast, the slope of the calibration curve of $\mathrm{tBuOOH}$ is 0.064 which is just $37 \%$ of the other standards. The reactivity of $\mathrm{tBuOOH}$ may be reduced due to the donating inductive effect of the tert-butyl group, which stabilises the O-O-bond of the peroxide group. Moreover, the tert-butyl group is known to protect neighbouring atoms sterically. Di-tert-butyl peroxide being stabilised by two tertiary aliphatic groups is known to be not reactive at all in the iodometric reaction (Banerjee and Budke, 1964). We conclude that we can only measure reactive peroxides quantitatively.

In Fig. 3b, we extended the measurements of $\mathrm{H}_{2} \mathrm{O}_{2}$ standard solutions up to $25 \mu \mathrm{M}$ by using the absorbance values recorded at $470 \mathrm{~nm}$. Due to the lower absorbance at this wavelength the measurement range can be extended to higher concentrations. Figure 4 shows the averaged values for the four reactive peroxides $\mathrm{H}_{2} \mathrm{O}_{2}$, BenP, LP and PAA at $420 \mathrm{~nm}$. Herein each curve was first blank corrected (i.e. intercept $=0$ ) and the absorbances were averaged for each peroxide concentration. From least squares linear regression, we obtained a slope of $0.174 \mu \mathrm{M}^{-1}$ with a $R^{2}$ of $99.96 \%$ which defines the sensitivity of the method (Inczedy et al., 1998). This sensitivity was used to calculate the content of peroxides in aerosols from smog chamber experiments.

Measurements of blank filters with KI at different days yielded an averaged blank signal of $0.06 \pm 0.006$. From this we derive a limit of detection $\left(c_{\mathrm{L}}\right)$ of $0.1 \mu \mathrm{M}$ (background 

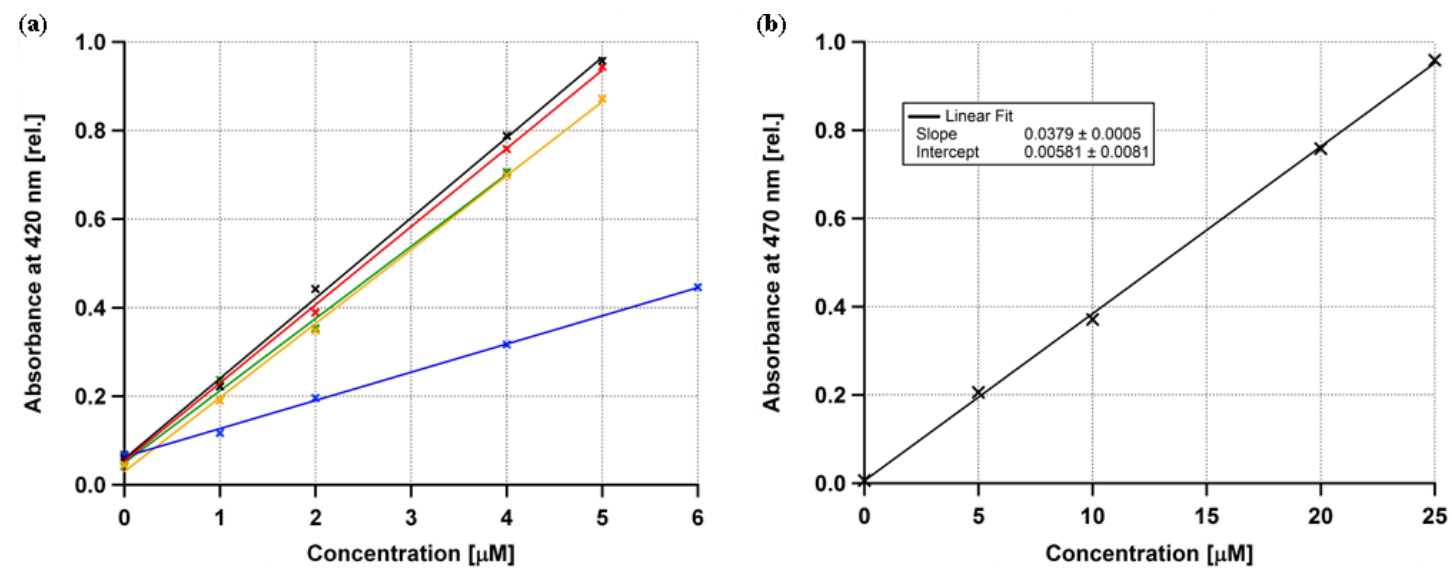

$\mathbf{x}$ Hydrogen peroxide $\mathbf{x}$ Benzoyl peroxide $\times$ Peracetic acid $\mathbf{x}$ Lauroyl peroxide $\mathbf{x}$ tert-Butyl hydroperoxide

Fig. 3. (a) Calibration curves for absorbance data at $420 \mathrm{~nm}$. Linear fits are shown for 5 different peroxides in the concentration range of $0 \mu \mathrm{M}$ (i.e. KI only) up to $6 \mu \mathrm{M}$. The slopes from these least squares linear regressions range between 0.064 (tert-butyl hydroperoxide) and 0.181 (hydrogen peroxide). The slope of the less reactive tert-butyl hydroperoxide is about 2.5 times lower compared to those of the other peroxides. (b) Calibration curve of hydrogen peroxide from the absorbance at $470 \mathrm{~nm}$. Peroxide concentrations range from $0 \mu \mathrm{M}$ (i.e. KI only) up to $25 \mu \mathrm{M}$. Least squares linear regression gives a $R^{2}$ of $99.94 \%$.

corrected signal). $c_{\mathrm{L}}$ was calculated according to Long and Winefordner (1983) and is equal to 3 times the background signal standard deviation divided by the sensitivity. With respect to smog chamber experiments our detection limit for a sampling volume of 5001 is $0.52 \mathrm{nmol} \mathrm{m}^{-3}$, which is about 2000 times lower than the one reported by Docherty et al. (2005). This allowed us to perform the smog chamber experiments at much lower initial $\alpha$-pinene concentrations.

\subsection{Reaction time of triiodide formation}

In order to explore the reason for the lower sensitivity of tertbutyl hydroperoxide and the optimal reaction time we performed calibrations with different reaction times while keeping the temperature at $40^{\circ} \mathrm{C}$. Figure 5 shows the temporal evolution of the absorbance at $420 \mathrm{~nm}$ from the triiodide formation for $2 \mu \mathrm{M}$ solutions of hydrogen peroxide $\left(\mathrm{H}_{2} \mathrm{O}_{2}\right)$, lauroyl peroxide (LP) and tert-butyl hydroperoxide (tBuOOH). For $\mathrm{H}_{2} \mathrm{O}_{2}$, the triiodide concentration reaches the maximum absorbance within $40 \mathrm{~min}$ and for LP within $60 \mathrm{~min}$, while for $\mathrm{tBuOOH}$ the reaction does not go to completion even after $5 \mathrm{~h}$.

This confirms that the different sensitivity for $\mathrm{tBuOOH}$ is mainly due to its much lower reactivity. We conclude that when using a reaction time of $60 \mathrm{~min}$, we are able to quantify the reactive peroxide species, i.e. $\mathrm{H}_{2} \mathrm{O}_{2}$, peracids and peroxides with vicinal carbonyl groups. In contrast, sterically protected and electronically stabilised peroxide species can not be captured quantitatively within $60 \mathrm{~min}$ even at an elevated temperature of $40^{\circ} \mathrm{C}$. This shows the limitation of the iodometric peroxide quantification and underlines the importance of a constant reaction temperature to assure the comparability of all measured absorbance values.

\subsection{Aerosol extraction}

Banerjee and Budke (1964) quantified peroxide residues in organic solvents via iodometry/photometry in acetic acid/chloroform (2:1 by volume). Recent studies about the quantification of peroxides in aerosol particles used ethyl acetate (Docherty et al., 2005), ethyl acetate/methanol (1:1 by volume) (Surratt et al., 2006) or water (Nguyen et al., 2010) for particle extraction. For the test reaction, a mixture of this extraction solution plus acetic acid/chloroform (Docherty et al., 2005; Surratt et al., 2006) or acetonitril/methanol (Nguyen et al., 2010) was then used. In our method we use aqueous hydrochloric acid solution $(0.1 \mathrm{M})$ and ethanol (1:1 by volume) for three reasons: (a) many solvents like esters contain large amounts of peroxide impurities; (b) the polyimid coating of the glass fibers is not inert to mixtures of organic acids with esters; (c) due to evaporation losses, highly volatile organic solvents are not suitable for our purging procedure with ultrapure nitrogen to remove oxygen.

To assess the extraction efficiency of our method for peroxides with low water/alcohol solubility, such as benzoyl peroxide (BenP) or lauroyl peroxide (LP), we spiked Teflon filters with defined amounts of BenP or LP dissolved in ethyl acetate (see Sect. 2.3). Then we analysed these filters for their peroxide content. We found the expected amount of these peroxides with our solvents as demonstrated by the corresponding calibration curves in Fig. 3a. Compared to the slope of the $\mathrm{H}_{2} \mathrm{O}_{2}$ calibration curve, the slope of BenP reaches $90 \%$ and of LP even $98 \%$ of this value.

Another important aspect of the extraction technique relates to the recently shown ability of different types of secondary organic aerosol (SOA) to produce $\mathrm{H}_{2} \mathrm{O}_{2}$ under aerobic conditions in aqueous solution (Wang et al., 2011). 


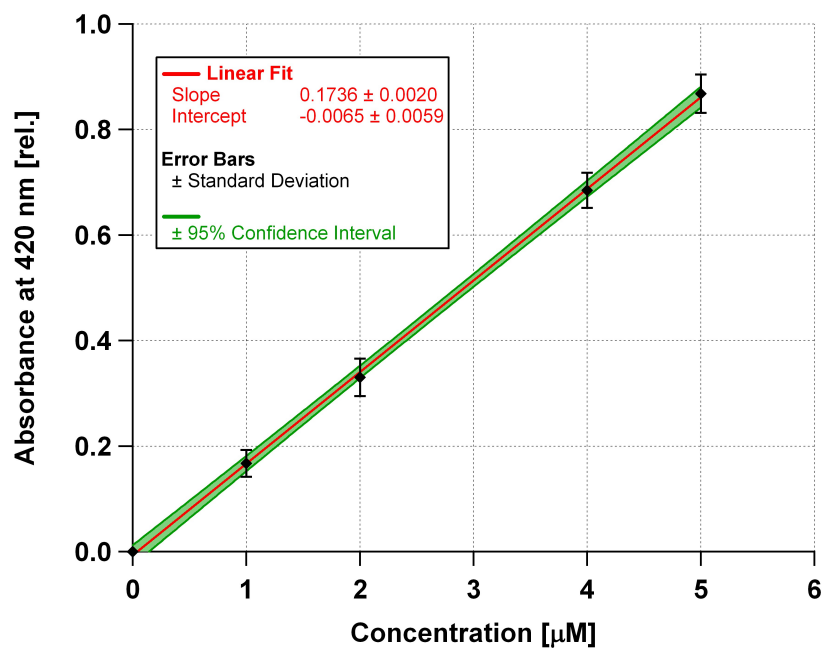

Fig. 4. Average of calibration curves from hydrogen peroxide, benzoyl peroxide, lauroyl peroxide and peracetic acid. Measurements were blank corrected and absorbance values averaged for each concentration. Error bars represent \pm standard deviation. The green area illustrates the $95 \%$ confidence interval. The slope of this curve was used to calculate peroxide concentrations from the smog chamber experiments.

This phenomenon was already observed earlier by an exceedance of Henry's law by $\mathrm{H}_{2} \mathrm{O}_{2}$ associated with aerosols (Arellanes et al., 2006). The authors suspected that the sampled particles are capable of generating $\mathrm{H}_{2} \mathrm{O}_{2}$ in aqueous solution. Moreover, redox cycling abilities of $\mathrm{PM}_{2.5}$ have been reported already a decade ago (Squadrito et al., 2001). All three cited studies performed the peroxide extraction of aerosols under aerobic conditions and hence did not exclude possible $\mathrm{H}_{2} \mathrm{O}_{2}$ formation during extraction. In our PeroxideLOPAP the sampled particles are extracted under anaerobic conditions to avoid in-situ $\mathrm{H}_{2} \mathrm{O}_{2}$ production.

\subsection{Peroxides in SOA from $\alpha$-pinene}

With our new instrument we analysed secondary organic aerosol particles produced in the PSI smog chamber. This is a $27-\mathrm{m}^{3}$ flexible Teflon bag suspended in a temperature controlled wooden enclosure (Paulsen et al., 2005). Four xenon arc lamps combined with 80 black light lamps (SUN POWER Performance $100 \mathrm{~W}$ ) are used to simulate the solar light spectrum and induce photochemical reactions. SOA was produced from $\alpha$-pinene as biogenic precursor. The experiments were done at $20^{\circ} \mathrm{C}$. A scanning mobility particle sizer (SMPS, consisting of a differential mobility analyser (DMA, TSI 3071) and a condensation particle counter (CPC, TSI 3022)) measured the particle size distribution, which was converted to a mass concentration assuming spherical particle geometry with a density of $1.3 \mathrm{~g} \mathrm{~cm}^{-3}$ (Alfarra et al., 2006; $\mathrm{Ng}$ et al., 2007). $\mathrm{O}_{3}, \mathrm{NO}$, and $\mathrm{NO}_{2}$ were all continuously monitored.

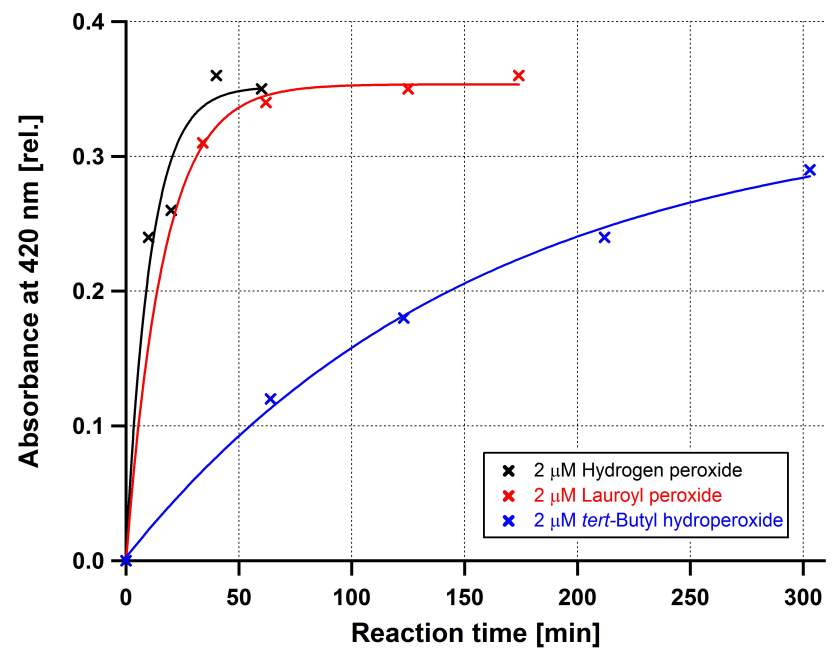

Fig. 5. Time evolution curves for the conversion of iodide ions to triiodide via molecular iodine (at an iodide concentration of $63 \mathrm{mM}$ ). The diagram presents three exponential fits for $2 \mu \mathrm{M}$ solutions of hydrogen peroxide, lauroyl peroxide and tert-butyl hydroperoxide at $40^{\circ} \mathrm{C}$. Background levels are subtracted.

The amount of peroxide functional groups was measured and normalised to the aerosol mass collected. Finally, total peroxide concentrations were determined in aerosol particles as a function of chemical age. The molecular weight of peroxides was assumed to be $300 \mathrm{~g} \mathrm{~mol}^{-1}$, equal to Docherty et al. (2005).

\subsubsection{SOA from ozonolysis of $\alpha$-pinene}

After setting the relative humidity to $50 \%, \mathrm{O}_{3}$ was added to the smog chamber followed by n-butanol as $\mathrm{OH}$ scavenger and $\alpha$-pinene (Aldrich, $98 \%$ ). Initial concentrations of reactants were $90 \mathrm{ppb}$ of $\alpha$-pinene, $9.4 \mathrm{ppm}$ of n-butanol and $500 \mathrm{ppb}$ of $\mathrm{O}_{3}$. The reaction started with $\alpha$-pinene injection and the mixture was allowed to react and age for $10 \mathrm{~h}$. Ozonolysis of $\alpha$-pinene was complete after $95 \mathrm{~min}$. Four filter samples (pore size $3.0 \mu \mathrm{m}$ ) were taken during the experiment and analysed for peroxides as well as original aerosol absorbance. Sampling times ranged between 20 and $40 \mathrm{~min}$ (290-5901). At $420 \mathrm{~nm}$ all original aerosol samples showed very low absorbances of 0.001-0.002, which is small compared to the peroxide measurement uncertainty $( \pm 0.006$, see Sect. 3.1). Hence, the triiodide signals did not have to be corrected for this. The resulting time series of the peroxide content in the aerosol particles is given in Fig. 6 (red line). The peroxide mass fractions in the suspended particles ranged between $34 \%$ and $12 \%$. It was highest in the first sample which was taken between 15-35 min of the reaction. After $4 \mathrm{~h}$ of aging, the peroxide content decreased to $17 \%$ and seemed then to stabilise at $12-13 \%$ after $6 \mathrm{~h}$. Both, Docherty et al. (2005) and Surratt et al. (2006) reported peroxide contents in SOA from $\alpha$-pinene ozonolysis of $47 \%$ and 


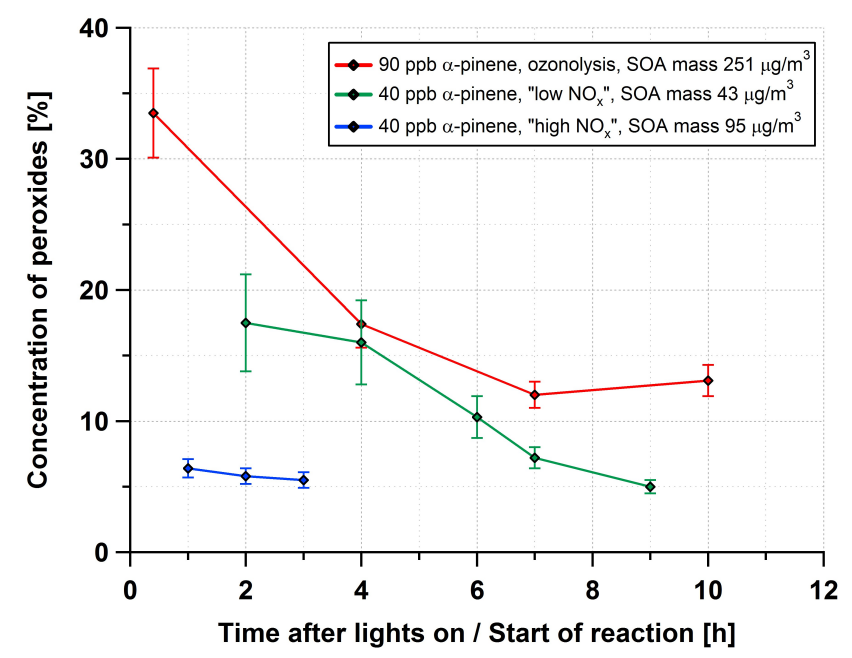

Fig. 6. Measured concentrations of peroxides in the aerosol particles after different reaction times in the smog chamber for ozonolysis as well as for photo-oxidation at low and high $\mathrm{NO}_{\mathrm{x}}$ of $\alpha$-pinene. An average molecular weight of $300 \mathrm{~g} \mathrm{~mol}^{-1}$ was assumed for the peroxides. Maximum suspended SOA levels are given in legend. Error estimation includes uncertainties of the absorption measurement, sensitivity, solvent volume and aerosol mass. The largest contribution to the error is from filter weighing.

$49 \%$, respectively. We assume that these cited values are not from aged aerosol but this remains unclear from their papers. Docherty et al. (2005) assumed a density of $1 \mathrm{~g} \mathrm{~cm}^{-3}$ for the aerosol volume concentration from their SMPS measurements. Recalculating their peroxide content with a density of $1.3 \mathrm{~g} \mathrm{~cm}^{-3}$ as used by us yields $47 / 1.3=36 \%$, which is in good agreement with our first sample measurement. The aerosol density used by Surratt et al. (2006) is not reported in their paper.

\subsubsection{SOA from photo-oxidation of $\alpha$-pinene}

We performed two experiments with different $\mathrm{NO}_{\mathrm{x}}$ concentrations. First, nitrous acid (HONO) was added to the smog chamber as an $\mathrm{OH}$ radical source. As reagent solutions, $10 \mathrm{mM}$ sulfuric acid and $1 \mathrm{mM}$ or $3 \mathrm{mM}$ sodium nitrite solution were used in a HONO generator similar to the one of Taira and Kanda (1990). Gaseous HONO was purged into the chamber by pure air and the gas flow was adjusted to maintain a constant HONO level. The initial concentration of $\alpha$ pinene (98\%, Aldrich) was 40 ppb in both experiments. After reactants had been allowed to $\mathrm{mix}$ for $15 \mathrm{~min}$, the photooxidation reaction was started by switching on all lights.

In the first experiment the relative humidity was $53 \%$ and the initial NO concentration was $0.35 \mathrm{ppb}$. The reaction was continued for $10 \mathrm{~h}$. Five filter samples (pore size $1.0 \mu \mathrm{m}$ ) were taken during the experiments and analysed for peroxides as well as aerosol absorbance. Sampling times ranged between 60 and $120 \mathrm{~min}$ (535-10661). At $420 \mathrm{~nm}$, all sample extracts again showed a very low original aerosol absorbance of about 0.001 , which is small compared to the peroxide measurement uncertainty. As for the ozonolysis experiments, the triiodide signals did not have to be corrected for aerosol absorbance. The time series of the measured peroxide concentrations is included in Fig. 6 (green line). Although the maximum aerosol mass concentration as determined by SMPS measurements was only $43 \mu \mathrm{g} \mathrm{m}^{-3}$, the measured peroxide amounts were still at least 10 times above the limit of detection (LOD). Peroxide mass fractions ranged between $18 \%$ and $5 \%$. During the first four hours of the experiment, the mass fraction was constant at about $17 \%$ and decreased thereafter continuously, reaching $5 \%$ at the end of the experiment. The NO mixing ratio started to increase $4 \mathrm{~h}$ after lights on from the initial $0.35 \mathrm{ppb}$ to reach finally $1.8 \mathrm{ppb}$ at the end of the experiment.

In the second experiment HONO and $\alpha$-pinene were added to the smog chamber as described before. To generate higher $\mathrm{NO}_{\mathrm{x}}$ conditions via the HONO source, we used $3 \mathrm{mM}$ sodium nitrite solution and an increased flow of pure air to purge gaseous HONO into the chamber. We also introduced ammonium hydrogen sulfate as a seed aerosol. The mode of the seed aerosol was at a diameter of $48 \mathrm{~nm}$ and its initial mass concentration was $26.5 \mu \mathrm{g} \mathrm{m}^{-3}$. The relative humidity was set to $82 \%$ to provide a wet aerosol to the condensing secondary organic aerosol species. After 15 min of mixing, the photo-oxidation was started by turning on all lights. The initial NO mixing ratio was about $3.3 \mathrm{ppb}$ in the beginning, decreased during the first hour and stabilised at about $1.8 \mathrm{ppb}$. The SOA concentration reached a maximum of $95 \mu \mathrm{g} \mathrm{m}^{-3}$ after about $3 \mathrm{~h}$ of reaction. Aerosol particles were collected on impactor steel plates for $60 \mathrm{~min}$ ( $4301 \mathrm{each})$. Three samples were taken. The resulting peroxide concentrations in the first $3 \mathrm{~h}$ after lights on are given in Fig. 6 (blue line). The level slightly decreased from $6.4 \%$ to $5.5 \%$.

Peroxides are formed in the gas phase via the bimolecular combination of peroxy radicals $\left(\mathrm{HO}_{2}+\mathrm{RO}_{2}\right)$. Competitive to this channel, peroxy radicals are removed by NO to form $\mathrm{NO}_{2}$, alkoxy or $\mathrm{OH}$ radicals. We compared the simulated formation of the first generation peroxide product hydroperoxy-pinanol and the second generation product perpinonic acid for the two experimental cases using the master chemical mechanism (MCM 3.2, http://mcm.leeds.ac. $\mathrm{uk} / \mathrm{MCM} / \mathrm{home}$.htt). These two compounds were considered surrogates of peroxides which can partition into the particle phase. Both, hydroperoxy-pinanol and perpinonic acid concentrations were roughly a factor of three higher in the low $\mathrm{NO}_{\mathrm{x}}$ case after $3 \mathrm{~h}$ of simulation. This is in fairly good agreement with the three times higher peroxide content in the low $\mathrm{NO}_{\mathrm{x}}$ experiment compared to the high $\mathrm{NO}_{\mathrm{x}}$ experiment. 


\section{Conclusions}

Our new peroxide long path absorption photometer (Peroxide-LOPAP) is sensitive enough to quantify peroxide concentrations in smog chamber experiments at typical atmospheric concentrations of volatile organic compounds and aerosols. Moreover, we are able to take several samples during a smog chamber experiment to follow the trend of the peroxide content in the aging aerosol with a time resolution of about 0.3 to $1 \mathrm{~h}$.

The experiments performed confirmed the dependence of the peroxide concentrations on the $\mathrm{NO}_{\mathrm{x}}$ concentration. The peroxide levels were highest for the ozonolysis of $\alpha$-pinene and decreased with increasing $\mathrm{NO}_{\mathrm{x}}$ concentrations. Even at NO levels of 2-3 ppb, we could still measure peroxides in the aerosol. Model simulations predict a similar decrease in peroxide concentrations as observed between low and high $\mathrm{NO}_{\mathrm{x}}$ experiments. However, this could also be by accident. It may be that acylperoxynitrates might contribute to the measured signal. However, from a chemical point of view, these compounds are also peroxides. There is also the possibility that other oxidative compounds, e.g. quinones or metal ions, are present which could transform iodide into iodine. We do not expect either of these in our experiments but this might be an issue when this analytical method is applied to other samples.

Wang et al. (2011) observed $\mathrm{H}_{2} \mathrm{O}_{2}$ in SOA from $\alpha$-pinene photo-oxidation experiments at high NO levels. They speculated that $\mathrm{H}_{2} \mathrm{O}_{2}$ was likely formed in decomposition or hydrolysis reactions of hydroperoxides. The peroxide levels found in our study would be high enough to explain their observations of $\mathrm{H}_{2} \mathrm{O}_{2}$. Acid catalysed decomposition has been shown to be rather slow (Miner and Hagan, 1972; Seubold and Vaughan, 1953). Based on those data, we estimate that the decomposition of the reactive peroxides by hydronium ions would be below $5 \%$ within $60 \mathrm{~min}$. We also do not have experimental evidence for this effect. Surratt et al. (2006) could not detect peroxides in SOA from isoprene under high $\mathrm{NO}_{\mathrm{x}}$ conditions. This may be due to the fact that the peroxide amount was below their detection limit or the $\mathrm{NO}_{\mathrm{x}}$ levels were higher than in our experiment.

An interesting feature was observed from the time trends. Both for ozonolysis and low NO photo-oxidation, a decrease of the peroxide content over time was observed, although the aerosol mass did not increase any further. This indicates a decomposition or hydrolysis of a large fraction of peroxides in the aerosol within a few hours. Surratt et al. (2006) reported a similar observation from isoprene SOA produced under low $\mathrm{NO}_{\mathrm{x}}$ conditions.

Acknowledgements. This study was financially supported by the Swiss National Science Foundation as well as the FP7 project EUROCHAMP-2. The authors thank I. El Haddad and M. J. Rossi for helpful and inspiring discussions as well as R. Richter and G. Wehrle for their competent technical advice.
Edited by: H. Herrmann

\section{References}

Alfarra, M. R., Paulsen, D., Gysel, M., Garforth, A. A., Dommen, J., Prévôt, A. S. H., Worsnop, D. R., Baltensperger, U., and Coe, H.: A mass spectrometric study of secondary organic aerosols formed from the photooxidation of anthropogenic and biogenic precursors in a reaction chamber, Atmos. Chem. Phys., 6, 52795293, doi:10.5194/acp-6-5279-2006, 2006.

Arellanes, C., Paulson, S. E., Fine, P. M., and Sioutas, C.: Exceeding of Henry's law by hydrogen peroxide associated with urban aerosols, Environ. Sci. Technol., 40, 4859-4866, doi:10.1021/es0513786, 2006.

Atkinson, R.: Atmospheric chemistry of VOCs and $\mathrm{NO}_{\mathrm{x}}$, Atmos. Environ., 34, 2063-2101, doi:10.1016/s1352-2310(99)00460-4, 2000.

Atkinson, R. and Arey, J.: Atmospheric degradation of volatile organic compounds, Chem. Rev., 103, 4605-4638, doi:10.1021/cr0206420, 2003.

Banerjee, D. K. and Budke, C. C.: Spectrophotometric determination of traces of peroxides in organic solvents, Anal. Chem., 36, 792-796, doi:10.1021/ac60210a027, 1964.

Bonn, B., von Kuhlmann, R., and Lawrence, M. G.: High contribution of biogenic hydroperoxides to secondary organic aerosol formation, Geophys. Res. Lett., 31, L10108, doi:10.1029/2003gl019172, 2004.

Callahan, M. R., Rose, J. B., and Byrne, R. H.: Long path length absorbance spectroscopy: trace copper analysis using a $4.4 \mathrm{~m}$ liquid core waveguide, Talanta, 58, 891-898, doi:10.1016/s00399140(02)00403-4, 2002.

Dobson, J. V. and Taylor, M. J.: The permeability of gases through PTFE and other membranes at 25-degrees-C, Electrochim. Acta, 31, 231-233, doi:10.1016/0013-4686(86)87113-4, 1986.

Docherty, K. S., Wu, W., Lim, Y. B., and Ziemann, P. J.: Contributions of organic peroxides to secondary aerosol formed from reactions of monoterpenes with $\mathrm{O}_{3}$, Environ. Sci. Technol., 39, 4049-4059, doi:10.1021/es050228s, 2005.

Faust, B. C., Anastasio, C., Allen, J. M., and Arakaki, T.: Aqueous-phase photochemical formation of peroxides in authentic cloud and fog waters, Science, 260, 73-75, doi:10.1126/science.8465202, 1993.

Giacobbe, F. W.: Oxygen permeability of Teflon PFA tubing, J. Appl. Polym. Sci., 39, 1121-1132, doi:10.1002/app.1990.070390508, 1990.

Hallquist, M., Wenger, J. C., Baltensperger, U., Rudich, Y., Simpson, D., Claeys, M., Dommen, J., Donahue, N. M., George, C., Goldstein, A. H., Hamilton, J. F., Herrmann, H., Hoffmann, T., Iinuma, Y., Jang, M., Jenkin, M. E., Jimenez, J. L., Kiendler-Scharr, A., Maenhaut, W., McFiggans, G., Mentel, Th. F., Monod, A., Prévôt, A. S. H., Seinfeld, J. H., Surratt, J. D., Szmigielski, R., and Wildt, J.: The formation, properties and impact of secondary organic aerosol: current and emerging issues, Atmos. Chem. Phys., 9, 5155-5236, doi:10.5194/acp-9-51552009, 2009.

Hasson, A. S., Orzechowska, G., and Paulson, S. E.: Production of stabilized Criegee intermediates and peroxides in the gas phase ozonolysis of alkenes 1 . Ethene, trans-2-butene, and 2,3- 
dimethyl-2-butene, J. Geophys. Res.-Atmos., 106, 34131-34142, doi:10.1029/2001jd000597, 2001.

Hecobian, A., Zhang, X., Zheng, M., Frank, N., Edgerton, E. S., and Weber, R. J.: Water-soluble organic aerosol material and the light-absorption characteristics of aqueous extracts measured over the Southeastern United States, Atmos. Chem. Phys., 10, 5965-5977, doi:10.5194/acp-10-5965-2010, 2010.

Heland, J., Kleffmann, J., Kurtenbach, R., and Wiesen, P.: A new instrument to measure gaseous nitrous acid (HONO) in the atmosphere, Environ. Sci. Technol., 35, 3207-3212, doi:10.1021/es000303t, 2001.

Inczedy, J., Lengyel, T., and Ure, A. M.: Compendium of Analytical Nomenclature (Definitive Rules 1997) - The Orange Book, 3rd ed., Blackwell Science, 1998.

Jimenez, J. L., Canagaratna, M. R., Donahue, N. M., Prévôt, A. S. H., Zhang, Q., Kroll, J. H., DeCarlo, P. F., Allan, J. D., Coe, H., Ng, N. L., Aiken, A. C., Docherty, K. S., Ulbrich, I. M., Grieshop, A. P., Robinson, A. L., Duplissy, J., Smith, J. D., Wilson, K. R., Lanz, V. A., Hueglin, C., Sun, Y. L., Tian, J., Laaksonen, A., Raatikainen, T., Rautiainen, J., Vaattovaara, P., Ehn, M., Kulmala, M., Tomlinson, J. M., Collins, D. R., Cubison, M. J., Dunlea, E. J., Huffman, J. A., Onasch, T. B., Alfarra, M. R., Williams, P. I., Bower, K., Kondo, Y., Schneider, J., Drewnick, F., Borrmann, S., Weimer, S., Demerjian, K., Salcedo, D., Cottrell, L., Griffin, R., Takami, A., Miyoshi, T., Hatakeyama, S., Shimono, A., Sun, J. Y., Zhang, Y. M., Dzepina, K., Kimmel, J. R., Sueper, D., Jayne, J. T., Herndon, S. C., Trimborn, A. M., Williams, L. R., Wood, E. C., Middlebrook, A. M., Kolb, C. E., Baltensperger, U., and Worsnop, D. R.: Evolution of organic aerosols in the atmosphere, Science, 326, 1525-1529, doi:10.1126/science.1180353, 2009.

Johnson, D., Jenkin, M. E., Wirtz, K., and Martin-Reviejo, M.: Simulating the formation of secondary organic aerosol from the photooxidation of toluene, Environ. Chem., 1, 150-165, doi:10.1071/en04069, 2004.

Kleffmann, J., Heland, J., Kurtenbach, R., Lorzer, J., and Wiesen, P.: A new instrument (LOPAP) for the detection of nitrous acid (HONO), Environ. Sci. Pollut. R., Special Issue 4, 48-54, 2002.

Kok, G. L., Thompson, K., Lazrus, A. L., and McLaren, S. E.: Derivatization technique for the determination of peroxides in precipitation, Anal. Chem., 58, 1192-1194, doi:10.1021/ac00297a047, 1986

Kroll, J. H. and Seinfeld, J. H.: Chemistry of secondary organic aerosol: formation and evolution of low-volatility organics in the atmosphere, Atmos. Environ., 42, 3593-3624, doi:10.1016/j.atmosenv.2008.01.003, 2008.

Lazrus, A. L., Kok, G. L., Gitlin, S. N., Lind, J. A., and McLaren, S. E.: Automated fluorometric method for hydrogenperoxide in atmospheric precipitation, Anal. Chem., 57, 917922, doi:10.1021/ac00281a031, 1985.

Long, G. L. and Winefordner, J. D.: Limit of detection, Anal. Chem., 55, A712-A714, doi:10.1021/ac00258a001, 1983.

Miner, F. J. and Hagan, P. G.: Rate of hydrogen-peroxide decomposition in nitric-acid solutions, Ind. Eng. Chem. Proc. DD, 11, 547-549, doi:10.1021/i260044a017, 1972.

Morio, L. A., Hooper, K. A., Brittingham, J., Li, T. H., Gordon, R. E., Turpin, B. J., and Laskin, D. L.: Tissue injury following inhalation of fine particulate matter and hydrogen peroxide is associated with altered production of inflammatory mediators and an- tioxidants by alveolar macrophages, Toxicol. Appl. Pharm., 177, 188-199, doi:10.1006/taap.2001.9316, 2001.

Ng, N. L., Chhabra, P. S., Chan, A. W. H., Surratt, J. D., Kroll, J. H., Kwan, A. J., McCabe, D. C., Wennberg, P. O., Sorooshian, A., Murphy, S. M., Dalleska, N. F., Flagan, R. C., and Seinfeld, J. H.: Effect of $\mathrm{NO}_{\mathrm{x}}$ level on secondary organic aerosol (SOA) formation from the photooxidation of terpenes, Atmos. Chem. Phys., 7, 5159-5174, doi:10.5194/acp-7-5159-2007, 2007.

Nguyen, T. B., Bateman, A. P., Bones, D. L., Nizkorodov, S. A., Laskin, J., and Laskin, A.: High-resolution mass spectrometry analysis of secondary organic aerosol generated by ozonolysis of isoprene, Atmos. Environ., 44, 1032-1042, doi:10.1016/j.atmosenv.2009.12.019, 2010.

Paulsen, D., Dommen, J., Kalberer, M., Prévôt, A. S. H., Richter, R., Sax, M., Steinbacher, M., Weingartner, E., and Baltensperger, U.: Secondary organic aerosol formation by irradiation of 1,3,5trimethylbenzene- $\mathrm{NO}_{\mathrm{x}}-\mathrm{H}_{2} \mathrm{O}$ in a new reaction chamber for atmospheric chemistry and physics, Environ. Sci. Technol., 39, 2668-2678, doi:10.1021/es0489137, 2005.

Pope, C. A. and Dockery, D. W.: Health effects of fine particulate air pollution: lines that connect, J. Air Waste Manage., 56, 709-742, 2006.

Pope, C. A., Ezzati, M., and Dockery, D. W.: Fine-particulate air pollution and life expectancy in the United States, N. Engl. J. Med., 360, 376-386, doi:10.1056/NEJMsa0805646, 2009.

Qi, X. H. and Baldwin, R. P.: Liquid-chromatography and electrochemical detection of organic peroxides by reduction at an iron phthalocyanine chemically-modified electrode, Electroanal., 5, 547-554, doi:10.1002/elan.1140050704, 1993.

Resnick, P. R. and Buck, W. H.: Teflon AF: a family of amorphous fluoropolymers with extraordinary properties, in: Fluoropolymers 2: Properties, edited by: Hougham, G., Plenum Press, New York, 25-33, 1999.

Seubold, F. H. and Vaughan, W. E.: Acid-catalyzed decomposition of cumene hydroperoxide, J. Am. Chem. Soc., 75, 3790-3792, doi:10.1021/ja01111a055, 1953.

Squadrito, G. L., Cueto, R., Dellinger, B., and Pryor, W. A.: Quinoid redox cycling as a mechanism for sustained free radical generation by inhaled airborne particulate matter, Free Radical Bio. Med., 31, 1132-1138, doi:10.1016/s0891-5849(01)00703$1,2001$.

Surratt, J. D., Murphy, S. M., Kroll, J. H., Ng, N. L., Hildebrandt, L., Sorooshian, A., Szmigielski, R., Vermeylen, R., Maenhaut, W., Claeys, M., Flagan, R. C., and Seinfeld, J. H.: Chemical composition of secondary organic aerosol formed from the photooxidation of isoprene, J. Phys. Chem. A, 110, 9665-9690, doi:10.1021/jp061734m, 2006.

Taira, M. and Kanda, Y.: Continuous generation system for lowconcentration gaseous nitrous-acid, Anal. Chem., 62, 630-633, doi:10.1021/ac00205a018, 1990.

Wang, K. X. and Glaze, W. H.: High-performance liquid chromatography with postcolumn derivatization for simultaneous determination of organic peroxides and hydrogen peroxide, J. Chromatogr. A, 822, 207-213, doi:10.1016/s00219673(98)00598-6, 1998.

Wang, Y., Kim, H., and Paulson, S. E.: Hydrogen peroxide generation from $\alpha$ - and $\beta$-pinene and toluene secondary organic aerosols, Atmos. Environ., 45, 3149-3156, doi:10.1016/j.atmosenv.2011.02.060, 2011. 
Williams, B. J., Goldstein, A. H., Kreisberg, N. M., and Hering, S. V.: An in-situ instrument for speciated organic composition of atmospheric aerosols: Thermal Desorption Aerosol GC/MS-FID (TAG), Aerosol Sci. Tech., 40, 627-638, doi:10.1080/02786820600754631, 2006.

Yao, W. S., Byrne, R. H., and Waterbury, R. D.: Determination of nanomolar concentrations of nitrite and nitrate in natural waters using long path length absorbance spectroscopy, Environ. Sci. Technol., 32, 2646-2649, doi:10.1021/es9709583, 1998.
Ziemann, P. J.: Aerosol products, mechanisms, and kinetics of heterogeneous reactions of ozone with oleic acid in pure and mixed particles, Faraday Discuss., 130, 469-490, doi:10.1039/b417502f, 2005. 